\title{
Cidadãos Transitórios: Práticas de habitação contenciosa na África do Sul contemporânea'
}

\author{
Transitory Citizens: Contentious Housing \\ Practices in Contemporary South Africa
}

\author{
Kerry Ryan Chance ${ }^{a}$
}

Tradução de Letícia Simões Gomes ${ }^{\text {b }}$

\begin{abstract}
Resumo O artigo examina práticas informais de moradia que pobres urbanos mobilizam para construir, transformar e acessar a cidadania na África do Sul contemporânea. Após a eleição de Nelson Mandela, em 1994, a provisão de habitações formais para pobres urbanos se tornou uma medida essencial para a inclusão política "não-racial" e a dessegregação de cidades sob apartheid. Contudo, assentamentos urbanos comemorados nas histórias de libertação como campos de batalha contra o apartheid - foram reclassificados como "favelas" (slums), zonas assinaladas para remoção ou desenvolvimento. Reintegrações de posse desses assentamentos para campos emergenciais do governo têm sido justificadas dentro da lógica liberal de expansão dos direitos à moradia, ligados à cidadania. Meu argumento é que as práticas informais de moradia evidenciam métodos de gestão de populações "faveladas", bem como a emergência de políticas do viver (living politics) em cidades sul-africanas.
\end{abstract}

Palavras-chave Apartheid; Cidades; Cidadania; Desenvolvimento; Despejo; Moradia; Pobreza; Raça.

Abstract This article examines the informal housing practices that the urban poor use to construct, transform, and access citizenship in contemporary South Africa. Following the election of Nelson Mandela in 1994, the provision of formalized housing for the urban poor has become a key metric for 'non-racial' political inclusion and the desegregation of apartheid cities. Yet, shack settlements-commemorated in liberation

Artigo originalmente publicado na Social Analysis (v. 59, n. 3, p. 62-84, 2015).

a Kerry Ryan Chance é professora do Departamento de Antropologia Social da Universidade de Bergen, na Noruega e é Associada Sheila Biddle da Fundação Ford pelo Instituto de Pesquisa W. E. B. Du Bois da Universidade de Harvard University. Ela publicou o livro "Living Politics in South Africa's Urban Shackland” (2017), que examina o governo e as mobilizações políticas de três cidades sul-africanas desde meados dos anos 1980 até hoje.

b Letícia Simões Gomes é mestranda pelo departamento de Sociologia da Faculdade de Filosofia, Letras e Ciências Humanas da Universidade de São Paulo (FFLCH/USP) e membro do corpo editorial da Revista Plural. 
histories as apartheid-era battlegrounds-have been reclassified as 'slums', zones that are earmarked for clearance or development. Evictions from shack settlements to government emergency camps have been justified under the liberal logic of expanding housing rights tied to citizenship. I argue that the informal housing practices make visible the methods of managing 'slum' populations, as well as an emerging living politics in South African cities.

Keywords apartheid, cities, citizenship, development, eviction, housing, poverty, race.

Eu conheci Monique duas semanas após o despejo. Ao nascer do dia, um grupo de policiais fortemente armados e agentes de segurança privada entraram em Delft, um distrito árido e castigado pelo sol nos arredores da Cidade do Cabo. Delft é o local da N2 Gateway, um projeto-modelo nacional para habitação urbana. Com veículos blindados e cães farejadores na guia, a equipe de reintegração de posse removeu cerca de 1.600 residentes de casas incompletas ocupadas dois meses antes, sob a alegada autorização de seu conselheiro local. Muitos tinham saído de barracos de madeira e lata corrugada, localizado nos quintais de proprietários vizinhos em distritos historicamente 'de cor' (mestiços) e 'Africanos'. As estruturas de concreto ocupadas pelos residentes eram chamadas "Casas BNG", em referência a uma política nacional, popular em 2004, chamada "Breaking New Ground". A política tinha como objetivo tornar a entrega de habitações estatais mais responsivas e eficientes, em parte por meio da expansão do papel do setor privado nesses programas.

O despejo, transmitido no jornal nacional noturno, foi violento. Sem aviso, a polícia atirou balas de borracha contra as multidões reunidas nas ruas, agredindo e atirando contra residentes enquanto estes corriam para se esconder. Ao menos vinte pessoas feridas foram levadas para o hospital, incluindo uma criança de 3 anos que fora atingida na barriga, perna e ombro. Sem ter para onde ir, Monique e cerca de mil outras pessoas permaneceram na rua. O governo municipal, junto da Aliança Democrática (Democratic Alliance, DA), o maior partido de oposição a situação no poder no Congresso Nacional Africano (African National Congress, ANC), respondeu providenciando aos membros das famílias despejadas grandes tendas comunais, algumas com estampas militares verde-escuro, outras com listras vívidas ou brancas com toldos de babados. Aos retardatários foram dadas 'velas negras', ou lonas plásticas, que foram usadas para construir pequenos barracos atrás das tendas, fora da vista das rodovias circundantes. O acampamento, refe-

2 "Explorando novas áreas”, em português (N.T.) 
rido pelos residentes como 'Seção 1', foi no fim das contas circundado com arame farpado e provido com torneiras de água e banheiros portáteis.

Todavia, Monique e aproximadamente outros 500 residentes se recusaram a trabalhar com a Aliança Democrática ou a assinar os formulários requeridos para adquirir espaço na Seção 1. Sob a bandeira da Campanha Anti-Despejo (Anti-Eviction Campaign, AEC), e liderando um movimento de pessoas pobres, eles construíram barracos a partir de uma variedade de materiais coletados no local de seu despejo. Eles fundaram um assentamento, Symphony Way (Caminho da sinfonia), nomeado a partir da rodovia que corre em seu centro, a qual por sua vez foi bloqueada por um protesto e ocupação de terra que durou mais de dois anos. Com o passar do tempo, as queixas coletivas dos residentes se centrariam não somente em seu despejo, como também nos acampamentos transitórios, os quais os ocupantes se referem por amathini ('latas' em isiZulu), blikkies ('pequenas latas' em Afrikaans), ou 'government shacks' ('barracos do governo' em inglês).

Acampamentos transitórios são abrigos de emergência do governo localizados em locais controlados. Os acampamentos acolhem aqueles desalojados por desastres ambientais comuns (como inundações ou incêndios) em assentamentos urbanos. Entretanto, a maior parte dos ocupantes do acampamento são aqueles deslocados por processos de desenvolvimento urbano, como a construção de estradas, pontes e projetos habitacionais como a N2 Gateway. Acampamentos transitórios geralmente tomam a forma de vilas de tendas, como a Seção 1, ou assentamentos construídos com latão corrugado ou outros materiais 'temporários'. Dezenas de milhares moram em acampamentos transitórios e muitos outros habitantes de barracos estão para serem realocados. Acampamentos transitórios estão rapidamente remoldando a periferia urbana da Cidade do Cabo e de outras cidades ao redor do país. O maior acampamento da África do Sul localiza-se em Delft. Os proponentes estatais dos acampamentos transitórios os retratam como intermediários 'formais' em direção à entrega de casas permanentes. Para moradores que se recusam à realocação, como aqueles da Symphony Way, as condições de vida nesses acampamentos são inadequadas, mesmo temporariamente e pelos padrões das moradias 'informais'.

Este artigo examina as práticas de moradia informal que pessoas como Monique e seus vizinhos mobilizam para construir, acessar e transformar a cidadania na geografia dinâmica da África do Sul contemporânea. Desde a eleição de Nelson Mandela em 1994, a ANC se focou no desmantelamento do apartheid e na extensão dos direitos contidos na política nacional e na nova Constituição Sul-Africana, em parte por meio da ‘erradicação’ de favelas e a promoção de moradias 
formais em grande escala (MAKнulu, 2010). Cerca de 2,4 milhões de casas foram construídas, mas o Estado pós-apartheid tem lutado para manter o ritmo ditado pela demanda esmagadora. Em 2009, o número de famílias em listas de espera oficiais para moradia na Cidade do Cabo era estimada a crescer de 20.000 para 400.000 ao longo do ano (Legassick, 2009). Em grande medida, esses números resultam das forças combinadas da urbanização e do alto desemprego após o apartheid, dados que o documento da política BNG assinala como desafio significativo para os programas nacionais de habitação, herdados do Estado de base racial. Com a suspensão das leis sobre mobilidade e outros dispositivos repressivos, centenas de milhares de pessoas se mudaram para áreas urbanas ou peri-urbanas à procura de emprego, educação e outras oportunidades sociais e econômicas previamente interditadas, muitas juntando-se aos já milhões de moradores de barracos. Desde o final dos anos 1990, protestos de rua, frequentemente centrados em moradia e terra, vêm se disseminando nacionalmente (Bond, 2004; PATEL, 2008; Pithouse, 2004). Essas manifestações têm sido oficialmente condenadas e dão origem a episódios rotineiros de violência sancionada, seja por policiais ou por forças de segurança privada, ocasionando a morte de oito manifestantes só no mês de janeiro de 2014 (Evans, 2014). Canais de notícias internacionais, bem como alguns nacionais, têm representado esses protestos como patologias no governo da África do Sul, como produto de expectativas inverossímeis ou altas da parte dos cidadãos, ou como sinal de corrupção e ineficiência da parte do Estado pós-apartheid. Entretanto, essa visão mais obscurece que revela os processos complexos nos quais as políticas habitacionais, como a BNG, se materializam por meio de interações cotidianas no espaço urbano entre moradores e agentes estatais.

Para melhor compreensão desses protestos, eu me concentrarei em práticas espaciais, as quais incluem nas cidades sul-africanas a construção de barracos, ocupações de terra, e mobilização de atividades na rua, tais como manifestações massivas e bloqueios viários. Conforme posto sucintamente pela antropóloga Julia Elyachar (2003, p. 574): "Quando práticas que violam leis são aceitas como normas e possuem uma legitimidade que não é a estatal, elas frequentemente são denominadas 'práticas informais". Como práticas de moradia, elas têm uma relação ambígua e até mesmo contenciosa para com as instituições que governam as áreas urbanas. Contudo, elas são tão comumente executadas que adquiriram o status de uma norma infraestrutural. Práticas informais nos auxiliam a compreender como a infraestrutura de habitação pode ser transformada pelos pobres que se recusam a ser removidos, que se apropriam de casas por ocupações ilegais ou que usam espaços carcerários como os acampamentos como plataformas para 
políticas coletivas. Aqui, desenvolvo a partir da noção de "pessoas como infraestrutura" do antropólogo AbdouMaliq Simone (2004). Este conceito sugere como habitantes urbanos, em especial "residentes com meios limitados", colaboram com "regularidade e provisioriedade" na circulação de bens, conhecimento e poder para construir uma "plataforma" que proporciona e reproduz "a vida citadina" (SIMONE, 2004, p. 407-408). Partindo dessas práticas espaciais de moradia informal, como a construção dos barracos na N2 Gateway, contribui-se para os esforços acadêmicos de expandir a noção de infraestrutura (normalmente restrita ou prefigurada por tubulações formais de água, estradas, unidades de habitação e energia elétrica) para conflitos Estado-cidadãos fundamentados nas atividades do dia-a-dia das pessoas e de suas vidas materiais (ver Chalfin, 2014; CHU, 2014).

Ademais, ao estudar tais práticas em uma conjuntura crítica, no momento em que as bases de um projeto-modelo de habitação nacional está sendo implantado, contribui-se para a compreensão das formas de conhecimento e expertise que interagem com (mas não são totalmente determinadas por) instituições formais na produção do espaço urbano. Acampamentos transitórios, que se parecem muito com barracos, ou pior, com tendas como aquelas da Seção 1, sugerem como habitações informais podem ser incorporadas pelo trabalho tecnocrático de Estado e organizações não governamentais.

Estudos recentes em infraestrutura, alguns seguindo o trabalho do filósofo urbano Henri Lefebvre, conferiram nova vida a como as teorias do espaço e da informalidade podem ser repensadas e recombinadas nas cidades africanas pós-coloniais do pós-Guerra Fria. De fato, até ativistas - incluindo a AEC - fizeram uso da famosa frase de Lefebvre "direito à cidade" em seus cartazes e comunicações à imprensa, enfatizando que o espaço não é pré-existente, ou um contêiner vazio, mas é vivido e construído (DE BRUIJN, 2005). Nos locais em que governos e corporações falharam ao prover habitações disponíveis e acessíveis, os pobres urbanos (e rurais) construíram suas próprias moradias, esquemas de aluguel, acordos de propriedade e vidas comunais. Aqueles sem moradia formal, por mais que desejem e aguardem sua entrega pelo governo, não o fazem passivamente. Antes, suas atividades constituem uma capacidade autônoma para a geração de crescimento econômico (HART, 1973) e de infraestruturas específicas para sua sobrevivência na cidade.

Por mais que seja importante reconhecer práticas espaciais dos pobres como geradoras, acadêmicos das últimas quatro décadas que são frequentemente críticos a como o setor tem sido operacionalizado pelos superiores (ver ELAYCHAR, 2003) proporcionaram muitos argumentos válidos contra a desconsideração da 
informalidade. Três objeções são particularmente comuns e relevantes no caso sul-africano. Em primeiro lugar, distinções categóricas ou ontológicas entre o formal e o informal reinscrevem antigas antinomias coloniais do moderno e o tradicional, o civilizado e o bárbaro, o cartográfico e a terra incógnita, os quais têm potencial para romantizar ou patologizar os pobres urbanos nas cidades africanas. Em segundo lugar, essa dicotomia não se sustenta em termos estritos, uma vez que características do setor informal podem ser encontradas no setor formal e vice-versa, especialmente em um contexto de urbanização e desemprego de uma economia globalizada. A terceira objeção consiste na existência de uma multiplicidade de setores formais e informais, sendo eles tão variados e contraditórios, interconectados e co-constitutivos em sua composição que essas categorias são por demais vagas para serem úteis. Entretanto, ao invés de abordar a informalidade em termos éticos ou analíticos, pode ser mais eficaz examinar a forma pela qual ativistas como Monique e os agentes estatais (particularmente, considerando a vida social de políticas como a BNG) mobilizam compreensões locais do informal, e o fazem estrategicamente com vistas a determinados fins políticos. Informalidade, então, enquanto uma categoria discursiva e um leque inovador de práticas de moradia torna-se palco de disputas sobre raça, classe e cidadania, mapeando e contribuindo para a produção do espaço urbano.

Eu baseio meus resultados em uma pesquisa etnográfica de longa duração, conduzida na Cidade do Cabo entre os anos 2005 e 2013. Além da observação participante em atividades cotidianas dos assentamentos e acampamentos transitórios, coletei entrevistas e histórias de vida com ativistas e moradores comuns sobre suas vidas durante e após as lutas de liberação, além de analisar materiais de arquivos relevantes, tais como documentos de políticas nacionais, legislação do pós-apartheid, mídia convencional e textos produzidos por militantes. Neste artigo, a partir das teorias do espaço urbano, moradia informal e pesquisa sobre movimentos políticos populares (ver ANAND, 2011; BERTELSEN et al., 2013; BRECKENRIDGe, 2014; Brenner et al., 2011; Desai, 2002; Fennel, 2013; Ghertner, 2011; Harms, 2013; Harvey, 2012; HerZfeld, 2009; Holston, 2008; JaCKson, 2006; Pieterse, 2008; Ross, 2010; Roy, 2011; SeEkings; NATtrass, 2005; Simone, 2012), procuro analisar, primeiramente, o uso ressurgente do termo 'favela' na África do Sul pós-apartheid, que, junto das reintegrações de posse de assentamentos 'informais' para acampamentos transitórios 'formais', intensificou-se ao longo da preparação para a Copa do Mundo da FIFA de 2010. Em seguida, seguindo os despejos na Cidade do Cabo, considero como a gestão das populações 'faveladas' em acampamentos transitórios reproduzem espacialmente desigualdades raciais históricas e precariedade peri- 
-urbana, apesar de serem focadas na redução da informalidade urbana por meio do preenchimento do vazio habitacional. Finalmente, demonstro como esses despejos forçados deram força à mobilização de moradores, baseadas na moradia e política informais, entre comunidades historicamente 'pardas' (ou mestiças) e 'africanas', apesar das tensões existentes entre as duas na alocação de habitações. Ao fazê-lo, sigo os passos de Monique pelas ruas, cortes e habitações em construção por Delft.

\section{A ASCENSÃO DAS 'FAVELAS' DO PÓS-APARTHEID}

Quando Monique e seus vizinhos ocuparam casas em Delft, a Cidade do Cabo estava se preparando para receber a Copa do Mundo da FIFA 2010. Esperava-se que milhares de visitantes cruzassem a rodovia N2 que conectava o aeroporto a glamorosos hotéis, atrações turísticas e estádio construído para a ocasião. Flanqueando esse corredor estão os distritos mais antigos e alastram-se os assentamentos urbanos. Em variados registros locais e nacionais na África do Sul contemporânea, essas áreas são caracterizadas como heroicos campos de batalha da luta pela liberação. Contudo, em 2008 o termo 'favela' ressurgiu - em novas leis, debates parlamentares, tabloides e notícias televisivas - para descrever as partes pobres marcadas para remoção ou desenvolvimento. Desde os anos 1930, o termo 'favela' tem sido associado na África do Sul aos esforços para se legislar zoneamentos raciais, frequentemente sob a égide do policiamento efetivo. O Estatuto das Favelas de 1934 foi um precursor colonial para as leis do apartheid. Ao proclamar as comunidades negras 'favelas', territórios eram apropriados pelos agentes do apartheid, especialmente na periferia urbana. Embora o termo 'favela' ainda tenha a conotação de zonas de miséria e criminalidade, a transição democrática conferiu novos significados. Favelas são "ruins para nosso país e para nosso povo", disse um agente da política de habitação ao Parlamento em 2007, exortando a expansão de programas de remoção em curso desde os anos 2000. Ele continuou: "Nós sonhamos com um amanhã no qual todos nós possamos legítima e orgulhosamente proclamar nossa cidadania... Nós sonhamos com um amanhã que seja livre de favelas"3. Nessa e em declarações análogas, despejos são justificados dentro da lógica liberal de direitos progressivamente garantidos, prometendo um futuro em que a cidadania materializada em habitações formais aja como um equalizador de uma comunidade política comum.

3 Discurso no Parlamento por Mike Mabuyakhulu, membro do Conselho Executivo de Habitação, Governo Local e Relações Tradicionais, em 19 de julho de 2007. Ver também Mabaso (2007). 
Não obstante, moradores da Cidade do Cabo e de outras cidades - como muitas outras durante o apartheid - resistiram ao termo 'favela' para falar de suas comunidades. Isso se dá especialmente por conta de a palavra ter sido usada tão amiúde durante realojamentos para áreas menos desejáveis, e sugerem transitoriedade quando comparada com residência de longo prazo, o que teria sido viável legalmente no pós-apartheid por intermédio da reivindicação de usucapião. Em resposta ao mesmo debate parlamentar, Abahlali baseMjondolo, um movimento de pessoas pobres vinculado à $\mathrm{AEC}$, colocou em uma nota à imprensa que a palavra 'favela' é usada “de maneira a representar esses espaços onde pessoas pobres moram como problemas... pois há algo de errado com essas pessoas... Mas não se admite que os pobres foram tornados pobres [pela] mesma história de pilhagem e exploração que fizeram dos ricos ricos e não admite que lugares onde pessoas pobres moram têm falta de infraestrutura e saneamento frequentemente por conta da omissão do governo em providenciá-los. A solução para o fato de que não temos banheiros em nossas comunidades é provê-los onde moramos, e não destruir nossas comunidade e nos realocar para fora da cidade"4. Ao apresentar uma réplica aos debates parlamentares, essa nota ecoa os sentimentos regularmente expressos pelos membros do movimento em reuniões comunitárias e manifestações de massa - particularmente que o termo 'favela' patologiza assentamentos, desumaniza seus moradores e invisibiliza lutas históricas contra o Estado anteriormente racial por terra e moradia. Ainda assim, o ponto de encontro entre os debates parlamentares e os membros desses movimentos é a invocação dos assentamentos urbanos com vistas a projetos de moradia para pobres urbanos, que implicitamente ligam a cidadania inclusiva à posse de terra e habitações formais.

Ao mesmo tempo, o termo 'favela' adere ao pânico nacional ao crime, percebido como crescendo exponencialmente desde a queda do apartheid. A política BNG cita "combate ao crime" e "promoção de coesão social" como partes integrantes de sua "nova visão de habitação"s. Todavia, o crime é fortemente racializado na África do Sul. Estereótipos de assentamentos urbanos ou de habitações no centro da cidade como casas de criminosos e prostitutas, marcados pela potencial poluição moral e degeneração corporal, aparecem regularmente nas mídias convencionais e populares sul-africanas. Em um artigo bastante representativo, um agente da política

4 “Operação Murambatsvina chega a KZN," comunicado de imprensa de Abahlali baseMjondolo, 21 de junho de 2007, http://www.abahlali.org/node/1629 (Acesso em 12 de julho de 2013).

5 Ver "Breaking New Ground: Um Plano Abrangente para o Desenvlvimento de Habitações Humanas Sustentáveis", agosto de 2004, http://www.thehda.co.za/uploads/files/ BREAKING_ NEW_GROUND_DOC_copy-2_1.pdf (Acesso em 12 de julho de 2013). 
habitacional caracteriza 'favelas' como "antro[s] do crime", recortados por "esgoto a céu aberto", combinando medos por insegurança com preocupações com a saúde pública ${ }^{6}$. Websites de viagem sul-africanos ecoam as recomendações familiares de classe média contra a visita a essas municipalidades: "Barracos de lata corrugada ... são locais de reprodução do crime e da violência ... A maioria de todos os crimes ocorrem nessas áreas faveladas"?. Quando um grupo de uma universidade local visitou um dos assentamentos onde eu conduzia minha pesquisa, suas questões focaram-se no porque os moradores de barracos que apareciam na mídia sempre tinham cometido crimes de natureza sexual - estupro e incesto. O morador, guia da excursão, respondeu: "Esse é o jeito como a mídia e as classes médias nos veem" e completou sardonicamente "Se você vir qualquer uma dessas coisas enquanto estiver aqui, por favor, chame a polícia".

Os moradores com quem conversei na Cidade do Cabo e em outras localidades sugerem que sua criminalização está parcialmente ligada a práticas espaciais tais como a construção de barracos e a ocupação de terras - que são ilícitas e por vezes ilegais, mas consideradas por eles necessárias para tornar a vida urbana viável e segura. "Os pobres são criminalizados pela vida que vivemos" disse Zikode, presidente fundador de Abahlali (comunicação verbal, ver também ZiкоDE, 2006). Porém, os residentes também sugerem que outros tipos de atividades políticas têm sido consideradas novamente ameaças à segurança pública. Desde 1994, a ANC e outros partidos políticos vêm se empenhando para a desmobilização das políticas populares de rua, características da luta pela liberação tardia, por meio do incentivo à participação em instituições democráticas formais, como o voto, a adesão a comitês locais e a dar entrada em subsídios para habitação. A DA, que governa a Cidade do Cabo, compartilhou a reprovação da intensificação dos protestos de rua por parte da ANC, atualmente no poder (Bond, 2004). Agentes oficiais referem-se a esses protestantes - e a Abahlali e membros da AEC em particular - como uma força 'criminal' sombria, representando uma "ameaça à democracia"s $\mathrm{em}$ potencial, ou uma "ameaça ao Estado" (BoyLE et al., 2005). Em 2005, uma investigação da inteligência nacional, geralmente destinada a riscos sérios à segurança nacional, foi iniciada com o objetivo de identificar agitadores pelo país.

6 “Jo'burg esvazia as favelas do centro da cidade” IOL News, http://www.iol.co.za/news/ south-africa/jo-burg-cleans-out-inner-city-slums-1.31118\#.UeHAekTNobo (Acesso em 12 de julho de 2013).

7 “Segurança e Crime na África do Sul” South Africa Travel, http://www.southafrica- travel.net/ miscellaneous/southafrica_safety.html (Acesso em 12 de julho de 2013).

8 “Mbeki fala de 'ameaça' de revoltas municipais na África do Sul” Agence France-Presse, 25 de maio de 2005. (Acesso em 12 de julho de 2013). 
Enquanto ‘favela' na África do Sul está marcada com suas significações históricas e regionalmente localizadas, seu uso durante as preparações para a Copa do Mundo refletiu seu reaparecimento no desenvolvimento internacional. Nas últimas décadas, instituições internacionais divulgaram estudos, projetos e programas incluindo o Objetivos de Desenvolvimento do Milênio da ONU de 2000 - para combater a 'expansão das favelas' em uma escala espacial diversa daquela dos governos nacionais de países em desenvolvimento, como África do Sul, Quênia, Índia e Brasil (DisterhofT, 2011). A África do Sul adotou tais objetivos completamente, incorporando-os às leis e políticas nacionais. Em 2007, agentes públicos sul-africanos da província de KwaZulu-Natal aprovaram um novo Estatuto das Favelas, em vistas de formar um novo modelo legislativo nacional. Tal estatuto, essencialmente centrado em acampamentos transitórios, visava à "eliminação ... [e] prevenção da reemergência de favelas" até o ano de 2014'. Enquanto o ano de 2008 marcou uma investida pela 'remoção de favelas', manteve-se a constatação que na África do Sul há mais pessoas vivendo e se instalando em barracos do que casas formais poderiam ser construídas no mesmo espaço de tempo. A 'erradicação das favelas' produziria uma população à espera de habitações formais, porém removidas de suas casas nos assentamentos. Para essa população haveria os acampamentos transitórios.

\section{ENTRE ESPAÇOS FUTUROS APOCALÍPTICOS E UTÓPICOS}

Em um número crescente de representações populares recentes, favelas e em especial as práticas espaciais que as constroem e sustentam são ilustrações poderosas em previsões apocalípticas e utópicas para um futuro próximo (ver RAO, 2006; Roy, 2011). Tais representações ressoam, amiúde literalmente, com as interações cotidianas entre residentes e agentes públicos sobre o espaço urbano da Cidade do Cabo e de outras cidades. Citando o bestseller de Mike Davis's (2006) Planeta Favela, um agente da política de habitação nacional na África do Sul afirmou, com ares sombrios, que o Projeto N2 "tinha como objetivo evitar uma catástrofe social iminente" (KoTsOANE, 2009) representada pelos assentamentos. No trabalho de Davis, favelas aparecem como uma cena saída de Blade Runner ou Mad Max, onde a vida se agarra aos detritos da economia informal, fora do alcance do Estado e da lei. Nesse mesmo tom, uma onda de estudos sobre favelas retratam comunidades pobres como 'lixões' humanos (ver também NeuwirTh, 1994; SEABROOK,

9 “A eliminação de KwaZulu-Natal e prevenção da reemergência do Estatuto das Favelas, 2007," Extraordinary Provincial Gazette of KwaZulu-Natal, 2 de agosto de 2007 http:// abahlali.org/ files/KZN\%20Slums\%20Act.pdf (acesso em 31 de outubro de 2015). 
1996). Inspirado pelos eventos passados e atuais de segregação racial na África do Sul, o blockbuster Distrito 9 de ficção científica (2009) representa os moradores de barracos como alienígenas, vivendo de restos em uma área abandonada por corporações multinacionais. O que essas imagens populares e disparatadas têm em comum é o retrato de 'favela' e 'favelados' como pessoas que esperam pelo desenvolvimento, na ausência do Estado.

As experiências de Monique e seus vizinhos, ao contrário, sugerem que o Estado não esteve ausente nos assentamentos. Nesse sentido, 'o Estado' deve ser compreendido não como uma totalidade unificada, mas como um leque de instituições hegemônicas, atores, discursos e táticas (ver ComarofF; ComarofF, 2006; Foucault, 1991; Gramsci, 1971; Sharma; Gupta, 2006). Assim, o Estado esteve mais do que presente: por agressões manifestadas pelas reintegrações de posse e violência policial. Essas formas de soberania estatal são bem lembradas por Monique como atividades definidoras das forças de segurança durante o apartheid. Favelas foram um objeto primário de legislação, política e regulação, tanto diretamente como pelo governo. Além disso, mesmo quando moradores carecem dos serviços necessários para uma vida urbana viável, eles tendem a entender essa ausência como a própria assinatura do Estado. Ou seja, a presença do Estado persiste mesmo quando uma comunidade não tem infraestrutura, como teto, água e eletricidade.

Sendo alvos prioritários da intervenção estatal e espaços de práticas de moradia contenciosa, esses assentamentos também aparecem em visões políticas utópicas de agentes estatais e ativistas na África do Sul pós-apartheid. "Caso consigamos lidar com o desafio das favelas" disse um agente da política habitacional sul-africano "nós teremos dado um grande salto em direção ao nosso objetivo de criar uma sociedade não-racial, não-sexista, democrática e próspera”ı . Com a queda do apartheid, a cidadania 'não-racial' prometia uma divisão igualitária na vida política e econômica, a dessegregação de espaços sociais e de sujeitos e o fim às funções violentas e arbitrárias do Estado. Para ativistas como Monique e esse agente público, moradia formal é símbolo-chave e métrica substantiva para uma transição estatal bem-sucedida. Contudo, os legados do colonialismo e do apartheid, junto de novas configurações ocasionadas pela globalização, austeridade e ajustes estruturais, aprofundaram as desigualdades entre os 'ricos e os ainda 'pobres' racializados. Os princípios econômicos estabelecidos pelo Banco

10 Legislatura provincial de KwaZulu-Natal. Debates e procedimentos da $3^{\text {a }}$ Legislatura provincipal

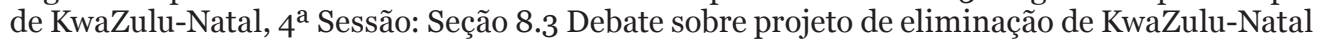
e prevenção da reemergência do Estatuto das Favelas, 2007. 
Mundial e o Fundo Monetário Internacional, frequentemente encobertos como liberalização econômica, orientaram a provisão de serviços básicos. Todavia, a ANC, cujas políticas nunca foram inteira ou diretamente neoliberais, continua a fazer da provisão de tetos o carro-chefe de sua plataforma eleitoral e a reivindicar os direitos de moradia em expansão garantidos pela nova Constituição sul-africana. Fazendo menção ao passado de apartheid e a promessa de um futuro democrático em distritos e assentamentos, a Seção 26 da declaração de direitos da Constituição afirma: "Toda e qualquer pessoa tem o direito a ter acesso à moradia adequada (...) Ninguém pode ser despejado de sua casa, ou tê-la demolida, sem uma ordem judicial"11.

A nova Corte Constitucional da África do Sul, desde sua primeira sessão em 1995, teve papel central para a adjudicação dessas novas demandas dos cidadãos a terras e moradia. A Corte Constitucional é a maior instância judicial da África do Sul. Em 2000, em um caso de demarcação de terras nomeado em referência à Irene Grootboom, moradora de barraco na Cidade do Cabo, a mais alta corte da África do Sul descobriu que a política de habitação nacional não dava conta de suas obrigações constitucionais (ver HuCHZERMEYER, 2004). A política redigida, Breaking New Ground, coincidiu com a construção do Projeto da N2 Gateway e o define como "projeto piloto"12. Tal qual a N2 Gateway, a BNG é um exercício dentro das contradições dos impulsos utópicos e apocalípticos de habitação, enfatizando ao mesmo tempo o objetivo de "superar as exclusões espaciais, sociais e econômicas" e autorizando a "erradicação" das favelas por meio de deslocamentos para "um rol de... tipologias de habitação" ${ }^{13}$, incluindo, evidentemente, os acampamentos transitórios. Embora tenha sido ostensivamente bem-sucedida nas cortes e contribuído para uma nova visão sobre habitação, compartilhada por especialistas e ativistas, Grootboom morreu em 2008 enquanto ainda vivia em um barraco na Cidade do Cabo, uma história bastante repetida nos assentamentos sul-africanos. Essa história é geralmente compartilhada em tom de aviso sobre as limitações das políticas institucionais formais, por dizer respeito à experiência real vivida nesses lugares.

11 Ver http:// www.justice.gov.za/legislation/constitution/.

12 Ver: abahlali.org/files/Breaking\%2onew\%20ground\%20New_Housing_Plan_Cabinet_approved_version.pdf

13 Ver: www.gov.za/about-government/government-programmes/sustainable-human-settlements-breaking-new-ground 


\section{UMA HISTÓRIA RECENTE DAS REINTEGRAÇÕES DE POSSE NA CIDADE DO CABO}

Aliados ao termo 'favela', despejos no pós-apartheid resultaram em conflitos constantes entre Estado e cidadãos na Cidade do Cabo, além de outras cidades sul-africanas. Monique, como seus vizinhos na Symphony Way, é uma residente de longa data de Delft e das Planícies do Cabo (Cape Flats). Durante as ordens colonial e do apartheid, as reintegrações de posse na Cidade do Cabo eram marcadas por uma combinação desigual de patronagem racial, extração de trabalho e violência soberana. Foi com as eleições do Partido Nacional em 1948, instituindo o apartheid, que o governo passou e posteriormente aplicou leis que atacavam a vida em assentamentos urbanos. Isso incluiu o notório Decreto de Agrupamento de Áreas de 1950 que levou ao rezoneamento racial da Cidade do Cabo e o Decreto para a Prevenção de Ocupações Ilegais de 1951. Munidos dessas leis, e no esforço de ruralizar trabalhadores negros desocupados, os distritos passaram iniciativas de remoção de 'favelas', contra as quais moradores - e especialmente mulheres - lutaram, por vezes combativamente. A remoção mais amargamente lembrada entre os moradores de Delft permanece sendo a demolição da icônica comunidade do Distrito 6, centro cultural e artístico pulsante, em que 60.00o pessoas foram desalojadas e dispersas pelas municipalidades da Cidade do Cabo. Um acampamento transitório precedeu uma remoção forçada parecida em Cato Manor, Durban, onde membros atuais e antigos da Abahlali residem. Em outras situações, os agentes estatais e corporações aliadas dos setores de mineração e têxtil toleraram ou facilitaram o crescimento das favelas, no intuito de manter a segregação racial e a disponibilidade de mão de obra barata. Acampamentos transitórios, então, eram usados para o monitoramento e repatriação de populações negras indesejadas. Advogados progressistas, nos ambíguos anos finais do apartheid, usaram a legislação sobre acampamentos transitórios para impedir a remoção de pessoas para zonas distantes e áreas de serviços. Ao longo dos anos 1970, período de instabilidade intensa, os campos também foram usados para desmobilizar movimentos políticos organizados.

Já na África do Sul pós-apartheid, novas leis - em especial o Decreto para Prevenção de Reintegrações de Posse de Ocupações de Terra Ilegais, de 1988 colocam medidas para evitar despejos arbitrários, estipulando que "acomodações alternativas adequadas" devam ser proporcionadas àqueles desalojados ${ }^{14}$. Uma série de casos judiciais, incluindo aqueles trazidos pela AEC e Abahlali, tratam principalmente da possibilidade de acampamentos transitórios serem enquadrados

14 Ver: http://www.saflii.org/za/legis/consol_act/poiefauoola1998627/ 
como esse tipo de acomodação. Por ora, as cortes concluíram predominantemente que sim. Contudo, despejos após 1994 - com e sem decisão judicial conforme a lei - tornaram-se rotineiros. Na Cidade do Cabo, justificativas oficiais para eles variam, sendo por vezes contraditórias. Essas incluem a construção de projetos de infraestrutura e serviços públicos, por exemplo, estradas e estádios, ou promovendo segurança pública ou proteção ambiental. De maneira geral, oficiais citam a natureza e os resultados do Estado de transição, o que envolve objetivos tais como integrar comunidades, concretizando novos direitos e, como as brochuras e anúncios indicam, construindo futuras 'cidades de classe mundial'. Como outros acadêmicos notaram (p. ex., GHERTNER, 2011), o termo 'cidade de classe mundial' é um projeto utópico. Seus objetivos e estética podem variar, mas é geralmente caracterizado por designs modernos e elegantes, altos níveis de eficiência estatal, lucratividade financeira e, se não sua eliminação, pelo menos a gestão ordenada da pobreza. Como sugerido pela então Ministra da Habitação Lindiwe Sisulu, na África do Sul a cidade de classe mundial é tanto sobre integração racial como sobre crescimento econômico para a nação como um todo. Ativistas, incluindo a AEC, apropriaram-se e relançaram o slogan, declarando que cidades de classe mundial são cidades sem despejos. Para Monique e seus vizinhos, reintegrações de posse trazem uma miríade de interpretações, além de nostalgia por lugares de penúria e por casas e comunidades demolidas há muito tempo. Há também um desejo afetivo por uma vida melhor, o cultivo da esperança por uma casa permanente ainda em vida - como seria mantida, que tipo de jardim poderia ter. Para alguns, realojamentos podem ser uma oportunidade para gerar receitas para a família, por exemplo, por meio de aluguel ou venda de uma casa BNG ou um abrigo em um acampamento transitório. Porém, os moradores com quem conversei observaram de forma geral e consistente que nos despejos podem ser vistas continuidades com as remoções do apartheid, além de novas formas de exclusão espacial, na intersecção de raça e classe. Acampamentos transitórios, eles sugerem, refletem três características dos despejos do pós-apartheid: (1) uma contenção de vidas que não são mais vitais para o trabalho, uma vez que os acampamentos abrigam majoritariamente pobres desempregados em áreas remotas; (2) uma privatização lícita e ilícita de funções estatais, já que os acampamentos são geralmente construídos e mantidos por parcerias público-privadas que envolvem propostas e contratos lucrativos; e (3) a ascensão de regimes técnicos poderosos para a instituição de políticas em esferas de reprodução doméstica, pois os campos demandam uma sempre-necessitada rede de especialistas, como advogados, analistas de impacto ambiental, arquitetos e engenheiros. 


\section{MORADIAS E DESPEJOS NA N2 GATEWAY}

Quando o projeto da N2 Gateway foi lançado, a Ministra da Habitação Sisulu - a filha de um dos famosos heróis da liberação da ANC - o chamou de "o maior projeto de habitação já feito por qualquer Governo"15. A literatura usada para a confecção do projeto propunha que, por meio da formalização da informalidade, o resultado seria a integração de diversas faixas de renda em 'assentamentos humanos' - um portal da cidade do apartheid para a cidade de classe mundial ainda por vir. No início, era uma iniciativa de vários níveis do governo. A gestão da N2 Gateway logo passou para Thubelisha, uma empresa privada cujo diretor se tornou o novo administrador do projeto, Príncipe Xhanti, empresário bem-sucedido de uma família real estimada do Cabo Leste. Um segundo nível composto de parcerias público-privadas, que incluiu o Primeiro Banco Nacional, operava entre o Estado e Thubelisha. Os planos originais mudaram com o passar do tempo, também por consequência da rotação e demissão de oficiais eleitos e parceiros do projeto. Contudo, a proposta aqui não é medir a que ponto a política se modificou da sua formulação inicial, pois isso aconteceria naturalmente. Antes, os planos deram pistas para compreender os pragmatismos de uma cidade de classe mundial compartilhada pelos agentes estatais em vários níveis de governo. Para os moradores de Symphony Way, os planos - em parte publicizados por meio da participação ativa da comunidade - são visto como necessários para compreender porque casas não finalizadas foram ocupadas e porque um assentamento urbanos foi levantado na N2 Gateway.

Das 25.00o habitações em construção, a maior parte delas servia para acumular valor para os investidores. O aluguel e os conjuntos habitacionais eram caros demais para os moradores dos barracos como Monique e seus vizinhos. Sua exclusão era em parte por design do projeto. O documento da política BNG identifica uma população média de famílias ganhando de R 3.500 a R 7.000 ao mês (aproximadamente US\$332 a 665) ${ }^{16}$. Os moradores de barracos não atingiram a faixa entre os mercados privados e governamentais de habitação. Os moradores inaugurais das casas de baixo-custo boicotaram o pagamento do aluguel por vários anos devido a não reparação de sérios defeitos por parte da Thubelisha, como grandes rachaduras nas paredes, tetos infiltrados e chaves disfuncionais. As chaves entregues aos moradores não abriam somente seus próprios aparta-

15 Comunicado de imprensa feito pela Ministra Sisulu em maio de 2006. Ver http://www.dhs.gov. $\mathrm{za} /$ content/media-statements/media-statement-24-may-2006 .

16 Ver: abahlali.org/files/Breaking\%20new\%2oground\%20New_Housing_Plan_Cabinet_approved_version.pdf 
mentos, mas todos aqueles no mesmo prédio, deixando a cargo dos residentes a criação de sistemas de segurança próprios. Os conjuntos habitacionais deveriam ser construídos nas terras ocupadas pelo assentamento Joe Slovo, de longa data, lar de cerca de 20.000 famílias. A última e única fase deixada para 'os pobres' consistia em moradias subsidiadas em Delft (as mesmas que foram ocupadas por Monique e seus vizinhos) e, para aqueles que permaneceram nas listas de espera para habitações formais, acomodações em acampamentos transitórios. Setenta por cento (70\%) das casas deveriam ser alocadas para moradores de barracos e 30\% para moradores de edículas (populações racialmente codificadas como 'africanas' e 'pardas', ou mestiças), fato que resultou em tensões entre comunidades, as quais posteriormente desestabilizariam a mobilização em Symphony Way.

Quando comecei minha pesquisa em 2008, jornalistas pouco noticiavam essa nova geração de acampamentos transitórios que adensavam a periferia urbana. Eles eram em boa parte invisíveis pelo ponto de vista dos subúrbios da classe média e do rico centro da cidade. A partir da pressão pública dos movimentos de pessoas pobres, em particular na Campanha Anti-Despejo da Symphony Way, as condições desses acampamentos foram cada vez mais reportadas pelas agências de notícias nacionais e internacionais, especialmente durante a Copa do Mundo da FIFA 2010. Nas minhas primeiras visitas, os portões do acampamento de Delft estavam fechados em determinadas horas, com um trailer policial e veículos militares blindados estacionados na frente da entrada. Como descobri em outros campos, o acesso é controlado com frequência. Os abrigos em Delft e nos acampamentos de Durban e Johanesburgo geralmente consistem em um ambiente, $20 x 26$ metros quadrados com telhados de lata corrugada e laterais, o que deixa pouco espaço para famílias mudarem ou crescerem, conforme indicado pelos residentes. Algumas estruturas, instaladas em fileiras, compartilham uma parede feita de uma só folha de metal. Seu tamanho é infelizmente comparável às casas do Plano de Reconstrução e Desenvolvimento, as estruturas de concretos mais comuns construídas depois de 1994, que tinham cerca de 30 metros quadrados com dois ambientes. Elas também são menores que as notórias casas 'caixa de fósforos', erigidas em distritos sob o apartheid, que compreendiam quatro ambientes e uma área de convivência em $52 \mathrm{~m}^{2}$.

Alguns, mas não todos, os campos têm latrinas comunais externas, torneiras de água gelada e medidores pré-pagos de energia elétrica. As dependências de cozinha variam se os moradores têm acesso à eletricidade pré-paga nos acampamentos ou têm gatos; nesse caso, chaleiras e fogões elétricos podem ser usados. Em ocasiões excepcionais, quando grandes porções de comida são preparadas, 
as mulheres fazem fogueiras na parte externa. Para aqueles que não têm eletricidade ou não podem pagar os medidores pré-pagos, o uso de fornos a parafina, fogueiras ou velas para iluminação são rotineiros e resultam em incêndios ocasionais. O acesso à água é variável. A maioria dos acampamentos está equipada com torneiras de água comunal, porém, quando essas estão quebradas, os moradores frequentemente dependem de vizinhos externos ao campo para água, causando por vezes tensões intercomunitárias. Basicamente coletadas por mulheres, a água é estocada em baldes dentro das casas. Banheiros comunais com frequência estão quebrados ou bloqueados, às vezes levando ao ponto da sua 'privatização' por residentes que os mantêm e cobram pelo seu uso. Sem banheiros funcionais, as pessoas tipicamente usam baldes com cal ou outros receptáculos ou métodos, como os 'banheiros voadores', que envolve simplesmente em aliviar-se em uma sacola e jogá-la o mais longe possível nos arredores.

No que tange a emprego, a maior parte dos residentes estão desempregados ou trabalham no setor informal, como em construções, trabalho doméstico, atividades ilícitas ou comércio ambulante. Alguns, contudo, trabalham no setor formal. O trabalho formal depende da localização do acampamento, mas é comum o trabalho em segurança privada por diversas cidades e regiões. Na maior parte das vezes, moradores são alojados não individualmente, mas enquanto uma 'comunidade' e frequentemente em campos com outras 'comunidades', o que gerou conflitos entre gangues rivais, especialmente em Delft. Por óbvio, os afazeres dessas pessoas ao longo do dia dependem largamente em se ou como elas estão empregadas, sua idade e gênero, entre outros fatores. Há muitas atividades comunais nesses espaços: projetos empreendedores como lojas spaza (pequenas lojas de conveniência) e shabeens (bares) que atraem multidões apesar dos esforços para controlá-los; grupos religiosos ativos de vários tipos (igrejas pentecostais e madrasas); associações voluntárias (creches e vigias noturnos); organizações políticas (movimentos sociais e estruturas partidárias) e comitês culturais (trupes de dança ou teatro e times de futebol).

Os acampamentos são tipicamente instalados longe de onde os residentes moraram por muitos anos. A erosão das redes de sociabilidade significa que moradores, em particular mulheres que precisam estar fora depois do entardecer, costumam temer por sua segurança. O que nos sugere que a localização importa. Muitos perderam seus empregos em áreas nas quais o transporte é mais caro e as lojas menos acessíveis. Aqueles sob medicação contra HIV/AIDS lutam para ter acesso ao tratamento nas clínicas próximas, mesmo no caso de ser um translado curto. As crianças de Delft, sem terem como ser acomodadas nas salas de aula 
locais, foram colocadas em escolas dos acampamentos temporários. Antes disso, elas eram transportadas para suas escolas nos distritos de origem, a cerca de 25 quilômetros de distância. Alguns acampamentos pós-apartheid adquiriram o status de assentamentos permanentes. O acampamento transitório Happy Valley (Vale Feliz), por exemplo, foi criado 14 anos atrás. Red City (Cidade Vermelha) é nomeado por conta da ferrugem que tomou conta das estruturas, antes reluzentes, de latão.

Da Cidade do Cabo a Durban, passando por Johannesburgo, seja por razões de sobrevivência, localização ou autonomia, moradores vêm protestando contra acampamentos transitórios por meio de redes políticas e jurídicas cada vez mais translocais e transregionais. Os moradores de Delft e de outros acampamentos ouviam sobre manifestações pelos vizinhos, em reuniões comunitárias, nas torneiras de água ou pontos de táxi, por mensagens de texto ou ainda por vê-las ao vivo nas ruas. Como Monique, esses manifestantes foram presos, alvos de balas policiais e retratados pelos agentes públicos como sabotadores do desenvolvimento social e econômico. Ao contrário das populações de favelas dóceis, disciplinadas e obedientes vislumbradas pelos planos da N2 Gateway, 'os pobres' da Symphony Way são vistos como desordeiros, perigosos e criminosos. A AEC e a Abahlali protestaram contra os acampamentos transitórios por meio de uma série de manifestações de rua e casos judiciais. Em 2009, Abahlali - junto dos moradores de Symphony Way na Corte Suprema da África do Sul - desafiaram e derrubaram o Estatuto das Favelas de 2009. De acordo com a nota de imprensa de Abahlali, os acampamentos projetam um futuro indefinido e precário para os moradores de barracos:

Nós temos uma situação na qual pessoas estão sendo removidas de uma favela e então enviadas para outra. Só que, desta vez, é uma favela aprovada pelo governo e chamada de área transitória ... [O Estado] não dá quaisquer garantias sobre onde essas 'áreas transitórias' ficarão, quais serviços serão providos, se comunidades serão mantidas juntas ou divididas... ou quanto tempo eles terão de viver nesses lugares. Nós sabemos que, ao longo da história e em vários países, governos colocaram seus oponentes políticos, os pauperizados, pessoas que eram vistas como étnica, cultural e racialmente diferentes, e pessoas sem registro de identidade em campos. Esses campos são sempre tidos como temporários - um 
'trânsito' entre um local e outro. Mas na maior parte das vezes esses campos se tornam espaços de longo e terrível sofrimento ${ }^{17}$.

\section{MORANDO EM CASAS FORMAIS E INFORMAIS EM DELFT}

Para complicar os espaços futuros projetados pela N2 Gateway, há múltiplos usos práticos que moradores fazem das habitações em Delft. Sentado com Monique na Symphony Way, na frente do escritório improvisado da AEC, conversamos sobre como ela tinha chegado ali. Para ela, a história da Symphony Way começou muitos anos antes, nos dias em que trabalhava com faxina nos subúrbios luxuosos da cidade. Ela vivia em uma edícula precária feita de madeira e placas de metal que alugava de um casal - eles mesmos mal conseguindo fechar o mês - que viviam em uma casa formal subsidiada pelo governo. Nas poucas vezes que a eletricidade funcionava, essa poderia ser desligada pelos proprietários, deixando-a a depender de velas e parafinas, ambas caras e perigosas.

Em busca de melhores condições, Monique se mudou para The Hague, uma das muitas áreas de Delft com nomes holandeses, para uma casa popular. Os proprietários, que a alugavam, viviam em outra zona das Planícies do Cabo. Quando oficiais locais descobriram esse arranjo - parte de um mercado 'cinza' de alugueis de moradias populares totalmente comum, inclusive de estruturas de acampamentos transitórios - os donos, sob ameaça de ação judicial pelo conselho, chegaram às 3 h da manhã para despejar Monique e sua filha, colocando seus pertences na rua. Monique apelou à polícia de Delft, explicando que tinha morado naquela casa por mais de um ano, não recebera qualquer aviso prévio de despejo e não tinha lugar para ir. A polícia lhe disse que ela não poderia levar o problema para a justiça, dado que não era a verdadeira proprietária da casa.

Após esse despejo, Monique e sua filha moraram na rua, na caçamba de uma bakkie (caminhonete picape). Quando seus empregadores na companhia de limpeza souberam de sua situação, eles a ajudaram a acessar acomodações em Delft por meio de suas conexões no Projeto da N2 Gateway. Junto com as vítimas de um incêndio massivo na ocupação Joe Slovo em 2005, Monique se mudou para um acampamento transitório chamado Tsunami. Durante sua estadia em Tsunami, especialistas descobriram que as paredes das estruturas temporárias eram feitas de amianto e isso se tornou uma questão de investigação criminal (JouBERT, 2007).

17 "Derrotar o Estatuto das Favelas" nota de imprensa de Abahlali baseMjondolo, 21 de junho de 2007, http://abahlali.org/node/1629 (Acesso em 28 de fevereiro de 2014). 
Sua filha então desenvolveu problemas brônquicos e de pele, que requeriam cuidados integrais, de forma que Monique largou seu trabalho. Ao final do ano, com contas médicas se acumulando, Monique começou a trabalhar para uma construtora contratada pela Thubelisha, fazendo fundações e instalando o encanamento para as casas da N2 Gateway em Delft. Ela ao final das contas entrou em greve, junto de outros trabalhadores temporários, declarando que nunca tinham sido pagos pelo serviço. Incapaz de manter sua subsistência básica, Monique e seus vizinhos mudaram-se para as casas desocupadas da N2 Gateway, usando de cartas oficiais - ainda que fraudulentas - que tinham sido emitidas pelo seu conselheiro local da DA, o qual foi posteriormente preso.

Thubelisha e agentes estatais rapidamente deram entrada e garantiram seu despejo por ordem judicial. Monique foi uma das partes no recurso derrotado. O Juiz da Suprema Corte Deon Van Zyl, que concedeu a ordem de reintegração de posse, ecoou outros oficiais, ao dizer que "a corte não pode sob hipótese alguma sancionar alguém que toma as leis em suas próprias mãos. O país cairia em anarquia se isso fosse permitido" (HAwkER et al., 2008). Essa referência à anarquia projeta outro tipo de futuro apocalíptico - o espectro da transição que falhou. Nesses comentários, o confisco de propriedades privadas são frequentemente evocados. "Benvindo ao Zimbábue" foi o comentário de um oficial quando o Estatuto das Favelas de 2009 foi derrubado. O parecer do Juiz Van Zyl nos remete ao passado recente, quando a ANC chamou à 'ingovernabilidade' dos municípios como forma de contribuir à queda do regime de apartheid. Finalmente, Monique e os demais moradores inferiram que 'anarquia', aqui, diz respeito aos medos racializados do crime.

Assim que o juiz levantou para deixar a corte abarrotada de gente, os moradores de Delft gritaram em afrikaans: "Ons gaan nêrens" (Não vamos a lugar algum) (HAwker et al., 2008). No dia da reintegração de posse, a vizinha mais idosa de Monique contou que depois de ter recebido tiros de bala de borracha na lateral do corpo e caído no chão, o policial a chutou e a xingou. No mesmo dia, o gabinete da Ministra Sisulu emitiu uma declaração na qual não havia nenhuma menção a ferimentos ou violência policial, registradas pelas câmeras dos repórteres. Citando os perigos da anarquia no centro de direitos progressivamente implementados, a versão oficial dos eventos se deu da seguinte maneira: "Nesta manhã, ao alvorecer, o Xerife da Corte foi à Delft, acompanhado pela polícia... O Estado de Direito deve prevalecer... [O] governo construiu... mais casa que qualquer outro país do 
mundo... A N2 Gateway ... é um projeto que deve ser alimentado e protegido por todos os sul-africanos"18.

\section{ACAMPAMENTOS TRANSITÓRIOS E LIBERALIZAÇÃO ECONÔMICA}

A literatura recente sobre estudos africanos e antropologia urbana vem ressaltando a interconexão de três processos de larga escala nas democracias pós-coloniais: governamentalidade, violência soberana e neoliberalização (ver Appadurai, 2006; Chatterjee, 2004; Ferguson, 2006; Hansen; Stepputat, 2005; Mamdani, 2011; Mbembe, 2003; McDonald; PaPe, 2002; Piot, 2010). Meu argumento é que acampamentos transitórios nos trazem reflexões sobre como esses processos estão intimamente ligados ao nível da infraestrutura habitacional. As aulas tardias de Michel Foucault são frequentemente citadas por essa literatura e são instrutivas para se pensar sobre o Projeto da N2 Gateway ${ }^{19}$. De acordo com Foucault (1991), o objetivo da soberania tradicional é fortalecer e proteger os frágeis e sintéticos laços entre território, população e governo por meio da identificação de perigos e do desenvolvimento de tecnologias para manipular relações de força. A "arte de governar" (FouCAult, 1991, p. 87) se preocupa, por sua vez, com “a disposição certa das coisas" (Foucault, 1991, p. 93, citando Guillaume de La Perrière), em que táticas - inclusive a própria lei - são mobilizadas para garantir a riqueza e bem-estar futuros de um "novo sujeito: a população" (Foucault, 1991, p. 101).

Um dos poucos e raramente notados exemplos de governamentalidade oferecidos pelo autor é um projeto de habitação do século XIX. Para Foucault, o desenho de um projeto habitacional - que, ao menos em teoria, localiza famílias pobres (uma por casa) e as posiciona espacialmente na cidade (na periferia) - tem o objetivo de controlar os corpos ao tornar indivíduos e seus comportamentos mais visíveis e o policiamento mais efetivo. Junto dessas medidas disciplinares centradas nos corpos, há mecanismos regulatórios para populações em vistas de "encorajar padrões de poupança relacionadas à moradia... e, em alguns casos, à sua aquisição. Sistemas de seguro-saúde, pensões para aposentados, regras sanitárias

18 Declaração emitida pelo Diretor-Geral do Departamento de Habitação, Itumeleng Kotsoane, dia 19 de fevereiro de 2008, http://www.dhs.gov.za/content/media-statements/ media-statement-21-february-2008 (accesso em 8 de maio de 2008).

19 Em História da Sexualidade, Foucault (1978, p. 95) argumenta que Maquiavel estava "entre os poucos... que concebiam o poder do Príncipe em termos de relações de força" e que seu projeto era levar adiante tal premissa, em que a persona do Príncipe é substituída por outros mecanismos de poder. Nas suas palestras, nos mesmos anos, que foram depois reunidas em uma publicação, Foucault (2003, p. 59) observa ainda que o poder disciplinar moderno - como um discurso de decepa o rei e opera sem soberano - deve denunciar as políticas principescas como "uma ilusão, um instrumento, ou, ao menos, um inimigo". 
que garantem a longevidade ótima da população, pressões para que a própria organização municipal lide com a sexualidade e procriação, cuidados com a infância [e] a educação" (FoucAult, 2003, p. 251) estão entre esses mecanismos. Ao mesmo tempo, o projeto habitacional fora pensado para remover os pobres urbanos dos cortiços abarrotados, considerados havia muito como criminais - e isso tem muito a ver com a soberania no seu aspecto mais gentil, a 'arte de governar'. O que Foucault não aborda, contudo, é como a infraestrutura pode ser transformada por práticas especiais pelos pobres, como a recusa à remoção, à ocupação ilegal de casas, a manipulação de contratos ou acordos de aluguel, ou o uso de espaços carcerários como os acampamentos como plataformas para políticas coletivas de resistência.

Retomando o Projeto da N2 Gateway, meu argumento é que mecanismos disciplinares e regulatórios que visam os corpos e populações dos 'pobres' estruturam e são estruturadas por violência soberana e liberalização econômica. Nos acampamentos transitórios de Delft, o capital privatizado flui para, dentre outros, Thubelisha, a companhia administradora; Eskom, a outrora multinacional pública que fornece eletricidade pré-paga aos moradores; o First National Bank, que autoriza obrigações e aluguéis; além da miríade de outros contratados para implementar o projeto, incluindo consultores, organizações sem fins lucrativos, construtoras e companhias de segurança privada. Nesse sentido, onde a soberania é concretizada, ela se difunde por meio de arranjos público-privados em vários níveis estatais e, por vezes, instituições globais. Foucault sugere que o projeto habitacional pode se tornar um local ainda mais efetivo para controle, vigilância e policiamento. Embora os acampamentos transitórios na África do Sul pareçam fazer jus a essa ideia, esses campos têm, ao invés, sido palco de condições de incerteza prolongada, o que impacta o potencial para mobilidade socioeconômica entre os pobres.

Ademais, os despejos indicam como a responsabilidade não tem endereço no que tange a demandas de moradia recentemente legitimadas pela lei pós-apartheid. Por exemplo, quando a crítica pública cresceu sobre as reintegrações de posse violentas na N2 Gateway, Sisulu declarou que ela havia instruído Thubelisha a fazer "qualquer coisa em seu poder para ajudar as pessoas de Delft ... para retorná-las aos seus locais prévios de acomodação" e para providenciar translados para aquele fim (PILlay, 2008). Príncipe Xhanti, administrador do projeto pela Thubelisha, negou tais diretivas e afirmou que "o Xerife da Corte era o único responsável” pelas reintegrações. O xerife, por sua vez, também negou responsabilidade, dizendo "A ordem [da Corte] diz que devo despejar as pessoas e remover os seus pertences para um lugar de custódia seguro. Foi isso o que fiz" (PIllay, 2008). Monique e os demais moradores, tendo desistido de suas moradias de fundos, não tinham outros lugares 
para ir após a reintegração que não fosse a rua. O porta-voz da polícia disse então que isso também era ilegal: "A ordem judicial instruiu os moradores a deixar a área... Era então ilegal que permanecessem na rua” (Sокоро et al., 2008). Ele ainda complementou que uma "guarda [de segurança privada] estava posicionada fora de todas as casas para prevenir que as pessoas retornassem" (Sокоро et al., 2008). Autorizados por modos governamentais dispersos de gerir populações 'faveladas', o poder soberano para despejar pode ter visado ao controle, mas ocasionou um protesto de dois anos que começou e acabou em precariedade peri-urbana.

\section{AS POLÍTICAS DO VIVER DOS 'POBRES'}

Sob essas condições, esses residentes mobilizaram uma política fundamentada na identificação coletiva como 'os pobres', presentes historicamente em comunidades de base racial, que se apoia em práticas antigas da luta pela liberação - tais como manifestações de massa e ocupações de terra - mas também em novas práticas, como a judicialização nas cortes recentemente dessegregadas. Os membros do movimento de pessoas pobres a denominam como 'Políticas do Viver' (ipolitiki ephilayo em isiZulu), um termo cunhado por Abahlali e frequentemente usados em seus encontros e manifestações públicas. Alguns moradores da Symphony Way, em especial aqueles mais jovens (como Monique), caracterizam suas atividades políticas, seu envolvimento com aquilo que chamam de 'a luta' (umzabalazo em isiZulu), como iniciadas com a queda do apartheid. Outros - como o vizinho de Monique, Ashraf Cassim, líder fundador da AEC - estiveram envolvidos com os movimentos de liberação em vários segmentos, inclusive a ANC, seja em operações militares, agrupamentos locais ou sindicatos.

Ao sentar-me com Cassim na Symphony Way, ele me contou a história das origens da Campanha Anti-Despejo (AEC), que começou em 1999 nas Planícies do Cabo. Após um período desempregado, Cassim trabalhou em uma editora responsável pela edição de compêndios de bolso da nova Constituição Sul-Africana. Foi assim que ele soube da Seção 26 e das proteções pós-apartheid contra despejos forçados. Do ponto de vista da unidade de habitação de sua mãe - em meio a medidas agressivas de recuperação de custos - remoções estavam se intensificando nas Planícies. Um idoso vizinho de sua mãe esteve entre os primeiros (de muitos) a serem forçados a sair de suas casas. Em resposta, os moradores orquestraram uma manifestação massiva, chamada de 'bloqueio', que prevaleceu sobre as forças de segurança e impediu a entrega da notificação de reintegração de posse, exigida 
por lei ${ }^{20}$. No dia seguinte, a polícia retornou com uma equipe militarizada. Nos comunicados de imprensa, os agentes públicos afirmaram que a AEC era uma fachada para gangues criminosas. Identificado como líder pelas forças de segurança, Cassim foi duramente agredido, seus dentes da frente quebrados por uma bota policial com biqueira de aço. O bloqueio, porém, resistiu. O homem idoso permanece em sua casa até hoje.

Políticas do Viver compreendem não somente protestos de rua, mas também atividades suscitadas pela vida cotidiana em distritos e assentamentos, como construir sem permissão ou desativar os medidores de eletricidade estatais. Deste modo, Monique e os demais moradores definem viver no asfalto da N2 Gateway - o que corresponderia a tempos longos e difíceis para muitos - como um modo de se representar em sua demanda por moradias definitivas. Monique viveu na Symphony Way em um barraco de dois cômodos, construído por ela com sucata coletada: anúncios de roupas, uma lona de plástico, pranchas de madeiras e um piso de linóleo com motivos. Dentro dele tinha-se uma cozinha e área de estar, cuidadosamente equipados com bancadas de isopor, um sofá bakki com almofadas e babados em cor malva e verde e cortinas.

Nas primeiras semanas, bloqueios com pneus, por vezes em chamas, eram instalados nas duas extremidades do assentamento para que veículos policiais não conseguissem entrar. Voluntários iniciaram e dirigiram uma creche, uma cozinha comunal, uma horta e um berçário. Uma ronda noturna patrulhava o assentamento até as primeiras horas do dia, especialmente para prevenir incêndios de velas ou fogueiras não vigiadas. Todas as noites, os moradores realizavam reuniões massivas da comunidade. Além das marchas no centro da Cidade do Cabo, os residentes também organizavam torneios de futebol e teatros informais sobre a vida no asfalto. Conforme as notícias da ocupação se disseminaram, eles acolheram jornalistas e ativistas de toda a África do Sul e do mundo. Sua história foi transmitida pela mídia impressa e televisiva, do The Guardian à Al Jazeera. Por meio dessas práticas e pelas 'favelas' escondidas pela cidade, Symphony Way visivelmente afirmou a existência de conflitos entre 'os pobres' e as parcerias público-privadas sobre o espaço urbano em desenvolvimento. Políticas do Viver, então, indica como moradores podem recorrer a instituições formais - por exemplo, por artigos constitucionais e políticas habitacionais nas cortes - e a atividades informais que promovem normas infraestruturais particulares.

20 Bloqueios se tornaram a resposta padrão da AEC para despejos na África do Sul, além de Chicago, Detroit e Los Angeles, onde novos ramos floresceram durante a crise imobiliária norte-americana. 


\section{O FUTURO DO FIM DAS 'FAVELAS'}

Ao longo de minha análise sobre as interações cotidianas entre moradores e agentes públicos no Projeto da N2 Gateway, argumentei que as práticas espaciais informais das pessoas pobres produzem infraestruturas que modelaram e ainda modelam o espaço urbano na África do Sul contemporânea. Ademais, essas práticas sofreram alterações sob as condições da democratização e da liberalização econômica. Ao fundir práticas antigas e novas que fazem dos 'pobres' espacialmente visíveis na cidade, as políticas do viver dão resposta a processos de larga escala que configuram a governança local e global na África do Sul. No pós-apartheid, 'o fim das favelas' na Cidade do Cabo e em outras cidades tem significado o despejo de moradores de favelas próximas aos centros urbanos e sua realocação em locais indesejáveis na periferia urbana, onde eles não conseguem pagar e têm pouco incentivo para permanecer. Enquanto os acampamentos transitórios são retratados como locais mais eficientes de vigilância e policiamento (bem como de manutenção do bem-estar biológico das populações 'faveladas'), o assentamento de Delft sugere como esses lugares conquistam o oposto daquilo previsto pela política pública.

Desde o início de minha pesquisa, o governo garantiu o despejo de 20.000 famílias do assentamento Joe Slovo, em Langa, para realocá-las em Delft. Os moradores, dentre os quais alguns que viveram ali por mais de duas décadas, foram à justiça para questionar sua remoção. A Corte Constitucional decidiu por negociações, as quais ainda estão em curso, após muitos anos e protestos violentos. Um panfleto da AEC descreve o dilema da seguinte forma: "É loucura burocrática tentar forçar os moradores do Joe Slovo para Delft, para as margens da cidade onde não querem viver, e ao mesmo tempo despejar coercitivamente os moradores de Delft de casas não demandadas pelos habitantes de Joe Slovo, e que são por aqueles desperadamente desejadas, pois não têm outro lugar para viver" (LEGASSICK, 2008, p. 40) O que os moradores de Joe Slovo estão demandando é a "construção de habitações na área para eles tem um plano de como isso pode ser executado sem nenhuma remoção forçada" (LEGASsick, 2008, p. 7). A proposta dos moradores incluem melhoramentos in situ e provimento de serviços básicos interinos onde vivem, o que reafirma alguns dos princípios estabelecidos pelo documento da BNG.

Para Monique e seus vizinhos, após outra extensa disputa judicial, sobrou sua remoção da Symphony Way. Alguns se espalharam por outros distritos e assentamentos nas Planícies, enquanto outros foram para acampamentos transitórios. Aqueles que permaneceram prosseguem pedindo coletivamente residência permanente em Delft. Monique disse que passou 19 anos na lista de espera oficial por uma casa. Muitos afirmam ter passado 30 anos e ainda guardam documentos 
do apartheid, dos anos 1980, para prová-lo. Para determinar quem poderia ser qualificado para uma casa na N2 Gateway, outra lista foi compilada pelo distrito, e outra ainda pela Thubelisha. Moradores se inscreveram nas delegacias, nos escritórios de Thubelisha e em vários outros lugares. Thubelisha, desde então, foi declarada insolvente após denúncias de corrupção do Cabo Oeste e em outras províncias. Príncipe Xhanti foi substituído. Por ora, enquanto os acampamentos transitórios são uma manifestação material das listas de espera, moradores têm pouca esperança de que tudo levará a uma casa de tijolos e argamassa. Contudo, alguns agentes públicos informam que a construção de acampamentos transitórios retroagiu devido a pressão pública exercida por moradores como Monique e seus vizinhos (comunicação verbal).

Ao examinar como moradores pobres ocupam papéis políticos visíveis a partir das margens da cidade, seja nas ruas, nas cortes ou na mídia internacional, minha consideração é de que os domínios legítimos da vida política estão sendo redefinidos por meio da produção de novas formas de cidadania e identidade, na intersecção de raça e classe (ver também CHARI, 2010). Contrariamente às representações apocalípticas e utópicas das favelas, que sujeitam os moradores à eterna espera pelo Estado desenvolvimentista ou a sua sangria, demonstrei como esses são espaços de próspera vida política e jurídica, com histórias complexas que revelam as contradições da experiência vivida quando justapostas às nítidas distinções de espaços formais e informais.

Este estudo enfatiza algumas das ambiguidades e ambivalências nas maneiras práticas pelas quais pessoas experienciam o mundo pós-colonial. Em um momento de recessão e intensificação dos protestos de rua por várias partes do mundo, os direitos econômicos - seu significado, adjudicação e status - estão sendo demandados por populações cada vez mais assertivas. Mais e mais, essas reivindicações estão sendo postuladas como jurídico-políticas e como demandas materiais por emancipação. Com a emergência dessas políticas do viver, o espaço urbano é prioritário e traz questões urgentes sobre a governança democrático-liberal, suas inclusões e exclusões. Conforme dito por Monique em nosso último encontro antes que ela desaparecesse da Symphony Way: "A razão pela qual eu acho que eu deveria poder estar aqui é porque sou uma cidadã e tenho direito à moradia. $\mathrm{E}$ é também sobre o futuro de minha filha... Eu não quero nunca mais viver em um barraco ou qualquer estrutura [do gênero]"21.

21 Comunicação verbal, 21 de maio de 2008. 


\section{AGRADECIMENTOS}

Essa pesquisa foi financiada pela Fundação Fulbright, o Conselho de Pesquisa em Ciências Sociais, a Fundação Andrew W. Mellon, a Fundação Wenner-Gren, a Sociedade Filosófica Americana, o Fundo de Doação Nacional para Humanidades, e o Centro Hutchins para Pesquisas Africanas e Afro-americanas da Universidade de Harvard. Eu gostaria de agradecer os editores da Social Analysis, especialmente Bjørn Enge Bertelsen. Agradeço também aos revisores anônimos e àqueles que leram os rascunhos anteriores, inclusos aqui Jean e John Comaroff, Hiba Bou Akar, Jeremy Schmidt, Sharad Chari, Mark Hunter e Marie Huchzermeyer. Foram muito apreciados os comentários dos membros do Departamento de Antropologia da Universidade de Harvard, o Centro de Estudos Indianistas na África da Universidade de Witwatersrand e dos moradores da Symphony Way, em Delft.

\section{REFERÊNCIAS BIBLIOGRÁFICAS}

Anand, Nikhil. Pressure: The PoliTechnics of Water Supply in Mumbai. Cultural Anthropology, v. 26, n. 4, p. 542-564, 2011.

APPADURAI, Arjun. Fear of Small Numbers: An Essay on the Geography of Anger. Durham, NC: Duke University Press, 2006.

Bertelsen, Bjørn; Tvedten, Inge; Roque, Sandra. 2013. Engaging, Transcending and Subverting Dichotomies: Discursive Dynamics of Maputo's Urban Space. Urban Studies, v. 51, n. 13, p. 1-18, 2013.

Bond, Patrick. South Africa's Resurgent Urban Social Movements. Centre for Civil Society

Research Report, n. 22, p. 1-34, 2004. http://ccs.ukzn.ac.za/default.asp?3,45,10,1398 (acesso em 28 de julho de 2012).

Boyle, Brendan; Philp, Rowan; Mвамbato, Sivuyile. South Africa: NIA Launches Probe into

Riots. Sunday Times, 29 de maio de 2005 http://allafrica.com/stories/ 200505310947. html (acesso em 13 de maio de 2008).

BRECKENRIDGE, Keith. Biometric State: The Global Politics of Identification and Surveillance in South Africa. Cambridge: Cambridge University Press, 2014.

Brenner, Neil; Marcuse, Peter; Mayer, Margit (Orgs.) Cities for People, Not Profit: Critical Urban Theory and the Right to the City. New York: Routledge, 2011.

Chalfin, Brenda. Public Things, Excremental Politics, and the Infrastructure of Bare Life in Ghana's City of Tema. American Ethnologist, v. 41, n. 1, p. 92-109, 2014.

CHARI, Sharad. State Racism and Biopolitical Struggle: The Evasive Commons in TwentiethCentury Durban, South Africa. Radical History Review, v. 108, p. 73-90, 2010.

Chatter.ee, Partha. The Politics of the Governed: Reflections on Popular Politics in Most of the World. New York: Columbia University Press, 2004. 
Chu, Julie Y. When Infrastructures Attack: The Workings of Disrepair in China. American Ethnologist, v. 41, n. 2, p. 351-367, 2014.

Comaroff, Jean; Comaroff, John L. (Orgs.). Law and Disorder in the Postcolony. Chicago: University of Chicago Press, 2006.

DAvis, Mike. Planet of Slums. London: Verso, 2006.

De Bruisn, Rosalie. The Poor Have the Right to be Housed in Well Located Land. Abahlali baseMjondolo, 30 de maio de 2005. http://abahlali.org/node/6750 (acesso em 24 de julho de 2014).

Desai, Ashwin. We Are the Poors: Community Struggles in Post-Apartheid South Africa. New York: Monthly Review Press, 2002.

Disterhoft, Jason. 11 Numbers You Need to Know about the Global Housing Crisis. Anistia Internacional, 6 de outubro de 2011. http://blog.amnestyusa.org/africa/humanright-to-housing-11-numbers-you-need-to-know/ (acesso em 23 de fevereiro de 2015). ELYACHAR, Julia. Mappings of Power: The State, NGOs, and International Organizations in the Informal Economy of Cairo. Comparative Studies in Society and History, v. 45, n. 3, p. 571-605, 2003.

Evans, Sarah. ANC to Take 'Firm Stance' on Violent Protestors. Mail \& Guardian, 6 de fevereiro de 2014. http://mg.co.za/article/2014-02-06-anc-to-take-firm-stance-onviolent-protesters (acesso em 18 de fevereiro de 2014).

Fennel, Catherine. 'Project Heat' and Sensory Politics in Redeveloping Chicago Public Housing. Ethnography, v. 12, n. 1, p. 40-64, 2011.

Ferguson, James. Global Shadows: Africa in the Neoliberal World Order. Durham, NC: Duke University Press, 2006.

Foucault, Michel. The History of Sexuality. v. 1: An Introduction. New York: Vintage Books, 1978.

Foucault, Michel. “Governmentality.” In: Burchell, Graham; Gordon, Colin; Miller, Peter (Orgs.). The Foucault Effect: Studies in Governmentality, Chicago: University of Chicago Press, 1991, p. 87-104.

Foucault, Michel. "Society Must Be Defended" In: Lectures at the Collège de France, 1975-1975. Trans. David Macey. New York: Picador, 2003.

GHertner, Asher. "Rule by Aesthetics: World-Class City Making in Delhi.” In: Roy, Ananya; ONG, Aihwa. Worlding Cities: Asian Experiments and the Art of being Global. Oxford: Wiley-Blackwell, 2011, p. 279-306.

Gramsci, Antonio. Selections from the Prison Notebooks. Hoare, Quintin; Smith, Geoffrey N. (Org. e trad.). New York: International Publishers, 1971.

Hansen, Thomas B.; Stepputat, Finn. Sovereign Bodies: Citizens, Migrants, and States in the Postcolonial World. Princeton, NJ: Princeton University Press, 2005. 
Harms, Erik. Eviction Time in the New Saigon: Temporalities of Displacement in the Rubble of Development. Cultural Anthropology, v. 28, n. 2, p. 344-368, 2013.

HART, Keith. Informal Income Opportunities and Urban Employment in Ghana. Journal of Modern African Studies, v. 11, n. 1, p. 61-89, 1973.

Harvey, David. Rebel Cities: From the Right to the City to the Urban Revolution. London: Verso, 2012.

Hawker, Dianne; Davids, Niemah; Samodien, Leila. We're Not Budging: Delft Residents. IOL News, 7 de fevereiro de 2008. http://www.iol.co.za/index.php?set_id=1\&click_ id=15\&art_id=vn20080207115012433C374131 (acesso em 8 de maio de 2008).

HERZFELD, Michael. Evicted from Eternity: The Restructuring of Modern Rome. Chicago: University of Chicago Press, 2009.

Holston, James. Insurgent Citizenship: Disjunctions of Democracy and Modernity in Brazil. Princeton, NJ: Princeton University Press, 2008.

Huchzermeyer, Mari. Unlawful Occupation: Informal Settlements and Urban Policy in South Africa and Brazil. Johannesburg: Africa World Press, 2004.

JACKSON, John L. “Gentrification, Globalization, and Georaciality.” In: CLARKE, Kamari M; Thомаs, Deborah A. (Orgs.). Globalization and Race: Transformations in the Cultural Production of Blackness. Durham, NC: Duke University Press, 2006, p. 188-205. Joubert, Pearlie. A Lethal Find. Mail \& Guardian, 1 de dezembro de 2007. http://abahlali. org/node/3033/ (acesso em 8 de maio de 2008).

KotsoAne, Itumeleng. N2 Gateway Taught Some Valuable Lessons. Mail \& Guardian, 10 de setembro de 2009.

LEgASSICK, Martin. Western Cape Housing Crisis: Writings on Joe Slovo and Delft. Panfleto, fevereiro de 2008 https://westerncapeantieviction.files.wordpress.com/ 2008/o3/ joeslovo_delft-leggasick.pdf

. Martin Legassick on the Macassar Land Occupation in Cape Town. libcom. org, 6 de maio de 2009. https://libcom.org/news/martin-legassick-macassar-villageland-occupation-cape-town-27052009.

Mabaso, Lennox. Slums Bill Not a Zimbabwe-Style 'Operation Murambatsvina.' The Witness, 18 de julho de 2007. http://abahlali.org/node/1720.

Maknulu, Anne-Maria B. “The Question of Freedom: Post-Emancipation South Africa in a Neoliberal Age.” In: Greenhouse, Carol J (Org.). Ethnographies of Neoliberalism. Philadelphia: University of Pennsylvania Press, 2010, p. 131-145.

Mbembe, Achille. Necropolitics. Public Culture, v. 15, n. 1, p. 11-40, 2003.

McDonald, David A; PAPE, John. Cost Recovery and the Crisis of Service Delivery in South Africa. New York: Zed Books, 2002. 
Neuwirth, Robert. Shadow Cities: A Billion Squatters, a New Urban World. New York: Routledge, 1994.

Patel, Raj. A Short Course in Politics at the University of Abahlali baseMjondolo. Journal of Asian and African Studies, v. 43, n. 1, p. 95-112, 2008.

Pieterse, Edgar. City Futures: Confronting the Crisis of Urban Development. London: Zed Books, 2008.

Pillay, Verashni. Delft Residents Stranded. 24 News, 19 de fevereiro de 2008. http://www. news24.com/SouthAfrica/News/Delft-residents-stranded-20080219.

Ріот, Charles. Nostalgia for the Future: West Africa after the Cold War. Chicago: University of Chicago Press, 2010.

Pithouse, Richard. "Our Struggle is Thought, on the Ground, Running” the University of Abahlali baseMjondolo. Centre for Civil Society Research Report, n. 40, 2004 http:// www.abahlali.org/files/RREPORT_VOL106_PITHOUSE.pdf (acesso em 29 de julho de 2012).

RAO, Vyjayanthi. Risk and the City: Bombay, Mumbai, and Other Theoretical Departures. India Review, v. 5, n. 2, p. 220-232, 2006.

Ross, Fiona. C. Raw Life, New Hope: Decency, Housing and Everyday Life in a Postapartheid Community. Cape Town: University of Cape Town Press, 2010.

Roy, Ananya. Slumdog Cities: Rethinking Subaltern Urbanism. International Journal of Urban and Regional Research, v. 35, n. 2, p. 223-238, 2011.

SЕAвRоок, Jeremy. In the Cities of the South: Scenes from a Developing World. London: Verso, 1996.

Seerings, Jeremy; Nattrass, Nicoli. Class, Race, and Inequality in South Africa. New Haven, CT: Yale University Press, 2005.

SHARMA, Aradhana; GuPTA, Akhil (Orgs.). The Anthropology of the State: A Reader. Oxford: Blackwell, 2006.

Simone, AbdouMaliq. People as Infrastructure: Intersecting Fragments in Johannesburg. Public Culture v. 16, n. 3, p. 407-429, 2004.

. "Screen." In: LuRY, Celia; WAKeword, Nina (Orgs). Inventive Methods: The Happening of the Social. London: Routledge, 2012, p. 202-218.

Soкоро, Asa; Williams, Murray; Makinana, Andisiwe. Delft Residents Refuse, Resist Eviction. IOL News, 19 de fevereiro de 2008 http://www.iol.co.za/news/south- africa/ delft-residents-refuse-resist-eviction-1.389942\#.VgsXwChy9oc

Ziкорe, S’bu. The Third Force. Abahlali baseMjondolo, 19 de outubro de 2006, http:// abahlali.org/node/17/ (acesso em 18 de fevereiro de 2014). 